\title{
Response of Chironomidae (Diptera) to impoundments in lowland
}

\section{streams}

\section{Maria Grzybkowska', Michał Kurzawski' and Małgorzata Dukowska'}

\author{
Grzybkowska M, Kurzawski M and Dukowska M. 2012. Response of Chironomidae (Diptera) to \\ impoundments in lowland streams. Fauna norvegica 31: 25-33.
}

\begin{abstract}
This study evaluated for one year the effects of three small dams located in low order sections of the Bzura, Mrożyca and Mroga Streams (central Poland) on their benthic communities (Chironomidae). Six sampling sites were established in these streams (one above and one below each dam reservoir) at a distance of several dozen $\mathrm{km}$ from one another, all these lotic ecosystems being a part of the Vistula drainage basin. The composition of benthic fauna at the upstream and downstream sites of each river was compared using multivariate techniques (CLUSTER and NDS). The downstream sites of these streams display different seasonal hydrological regimes due to management of the reservoirs and the amount of forested versus agricultural land use in their catchments. The highest macrobenthic density was observed

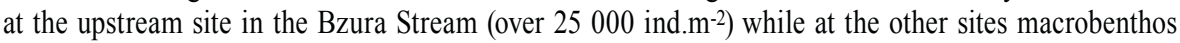
was less numerous. At each stream benthic macroinvertebrates were dominated by Oligochaeta and Chironomidae (midges constituted from over $30 \%$ to over $90 \%$ of the total macrobenthic density). In the upstream reaches due to small fluctuations of abiotic parameters (discharge) large populations of a small number of chironomid species (mainly Chironomini) dominated in the benthos, while in the downstream reaches a moderate disturbance enabled a much higher number of species to develop and coexist, but at a lower level of density than at the upstream sites (the Bzura and Mrożyca Streams). In turn when the size of inorganic substrate particles was larger (gravel) at the downstream site not only a higher number of species but also their higher density than in upstream site (the Mroga Stream) might be observed.
\end{abstract}

doi: 10.5324/fn.v31i0.1379. Received: 2011-10-14. Accepted: 2012-05-15.

Published on paper and online: 2012-10-17.

Keywords: stream disturbance, reservoir, benthos, Chironomidae

1. Department of Ecology \& Vertebrate Zoology, Faculty of Biology and Environmental Protection, University of Łódź, 12/16 Banacha Str., Łódź 90-237, Poland

Corresponding author: Maria Grzybkowska

E-mail:mariagrz@biol.uni.lodz.pl

\section{INTRODUCTION}

Chironomidae have a worldwide distribution due to their broad ecological tolerances. In lotic ecosystems, environmental factors such as disturbance regime/flow intermittency, inorganic substrate size, biome type (the quality and quantity of food resources, including amount of benthic particulate organic matter, BPOM) and annual temperature range were the most common factors affecting abundance and species diversity of these dipterans (Rossaro 1991; Vinson \& Hawkins 1998; Fesl 2002; Głowacki et al. 2011). Accordingly to Lehmann
(1971), Lenat (1987) and Lindegaard \& Brodersen (1995) high chironomid species richness in rivers is maintained not only by differences in their microhabitats by also by differences in their diet and seasonality.

In the history of modern civilization much stress has been put on river modification. According to many hydrobiologists river impoundment is one of the most pervasive human disturbances of the world's ecosystems (Ward \& Stanford 1980; Petts 1984; Bednarek 2001); these statements are based mostly on the analysis of the functioning of large rivers. The 
disruption of the upstream-downstream continuum of streams by damming has been much less studied (Armitage 1987, Palmer \& O’Keeffe 1990).

The main goal of our investigations is gaining knowledge of the response of chironomid assemblages to unnatural flow fluctuations caused by dams. Our investigations concerned three lowland streams in Poland, which differed by their discharge due to various functions of the dam reservoirs and by various inputs of allochthonous organic matter from their valleys. Thus a more clear understanding of physical-biological relationships allows deeper insights into the ecological organization of streams and improves our ability to predict how flow alterations caused by various human activities affect the lotic ecosystems.

\section{Study area}

The six study sites were established in three streams within the Vistula River drainage basin, including a considerable part of the Łódź Voivodeship (central Poland). The study sites were located on each river upstream and downstream of its reservoir, at 10 or more $\mathrm{km}$ apart (Figure 1).

All these rivers are a part of the Vistula drainage basin. The Bzura Stream arises at $235 \mathrm{~m}$ a.s.l., and is $166 \mathrm{~km}$ long; this river flows into the Vistula River at $64 \mathrm{~m}$ a.s.l. Its catchment area is $7787.5 \mathrm{~km}^{2}$ and the slope is $2.4 \%$ in the upper course. This stream flows in the vicinity of the Łódź city. Two study sites are located in a first order stream section: BZAu, the upstream site, are separated by three transient recreation ponds from BZAd, the downstream one (Figure 1). The largest pond (Arturówek Reservoir), the most downstream one, has an area of 3.05 ha and similarly to the others was constructed in 1963 , mainly for the recreation of Łódź inhabitants. Two phenomena influence the discharge of this urban reach at the downstream site: 1. the release of water through a small dam downstream of the recreation ponds, to facilitate their cleaning, was followed by slow re-filling, 2 . storm runoff, especially from roads. Large amounts of allochthonous organic matter, especially tree leaves, covered the stream bed of BZAd over the annual cycle because this stream flows across a forest. The other parameters of sites are given at Table 1.

The Mroga Stream is a right tributary of the Bzura Stream, its length is $61 \mathrm{~km}$, and basin area is $531.7 \mathrm{~km}^{2}$. Its sources are located in the Łódź Upland Landscape Park, at an altitude of 195 $\mathrm{m}$ a.s.l. The Mroga Stream flows into the Bzura Stream at $92 \mathrm{~m}$ a.s.l. In the second order section of the Mroga Stream two study sites were established, separated by the Bogdanka Reservoir: upstream site (MRAu) and downstream site (MRAd) (Figure 1). Historically, this one (and also other reservoirs) was used to power corn mills, saw mills and other industrial plants, including rolling copper and brass smelt works. Now this reservoir is maintained by the the Polish Angling Association. This stream flows through agricultural areas with many trees and bushes.

The Mrożyca Stream is a left tributary of the Mroga Stream, with a length of $27 \mathrm{~km}$, and the catchment area of 118.9 $\mathrm{km}^{2}$. Its sources are located at $180 \mathrm{~m}$ a.s.l., while the mouth 92 $m$ a.s.l. In the second order section of the Mrożyca Stream two study sites were established: one upstream from the Stara Piła Reservoir (MCAu) and the other downstream from it (MCAd) (Figure 1). The catchment area is agricultural area (mainly meadows) and forests. Now this reservoir is used by the Polish Angling Association.

The environmental parameters of these six sites are given in figure 2 and table 1; further details of these streams are presented by Grzybkowska (1995), Grzybkowska \& Głowacki (2011).

\section{MATERIAL AND METHODS}

Samples were collected at monthly intervals for one year from November 2007 to December 2008, in the Bzura, Mroga and Mrożyca Streams. The impact of the following riverine abiotic variables on species richness and density of macrozoobenthos were estimated: discharge, current velocity, width, depth, water temperature, dissolved oxygen and $\mathrm{pH}$. Ten samples were collected with a $25 \mathrm{~cm}^{2}\left(250 \mathrm{~cm}^{2}\right.$ of stream-bed area) tubular sampler at each site. Invertebrates from benthic samples were sorted by hand and preserved in 10\% formalin prepared with stream water. Chironomidae larvae were identified to species level (if possible) or from imagines obtained at laboratory rearing (from additional quantitative samples).

On the basis of these benthic samples we also determined BPOM (amount of two fractions benthic particulate organic matter, BCPOM, coarse- and BFPOM, fine POM, Petersen et al. 1989), TPOM (transported particulate organic matter), as well as periphyton (chlorophyll $a$ concentration, Golterman et al. 1978). We also estimated the granulometrity of inorganic substrate; SI is a single inorganic substrate index, obtained by

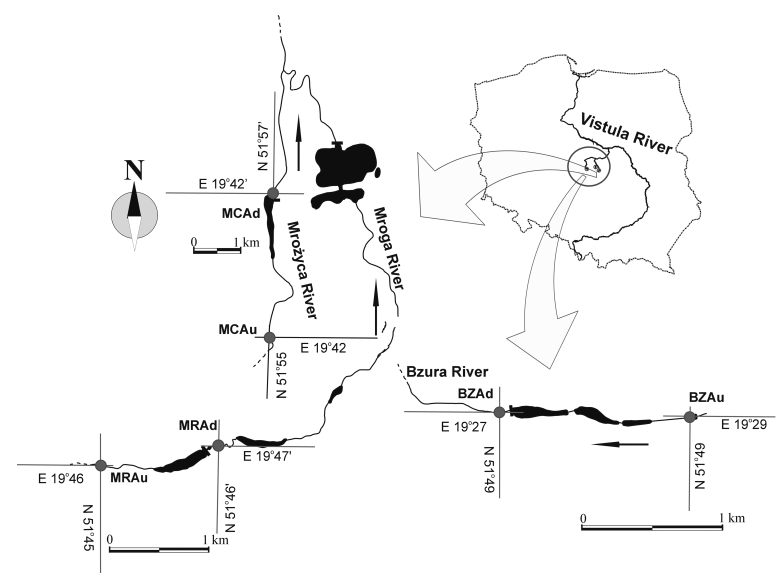

Figure I. Map of the study region and its location in Poland. Marked sampling sites at the Bzura Stream are BZAu (upstream) and BZAd (downstream), at the Mroga Stream MRAu (upstream) and MRAd (downstream), and at the Mrożyca Stream MCAu (upstream) and MCAd (downstream). 
Table I. Mean $(\overline{\mathrm{x}})$ and range $(\mathrm{R})$ of selected environmental parameters of the three lowland streams, the Bzura (BZA), Mroga (MRA) and Mrożyca (MCA) at each upstream (BZAu, MRAu, MCAu) and each downstream site (BZAd, MRAd, MCAd) of a respective reservoir over the annual cycle; SI - substrate inorganic index, BCPOM (coarse) and BFPOM (fine) particulate organic matter; TPOM - transported particulate organic matter; ${ }^{*}$ - statistically significant differences between each parameter of the upstream and downstream sites: $\mathrm{p}<0.05$, ${ }^{* *} \mathrm{p}<0.01,{ }^{* * *} \mathrm{p}<0.001$.

\begin{tabular}{|c|c|c|c|c|c|c|c|}
\hline \multirow{2}{*}{ Characteristics } & & \multicolumn{6}{|c|}{ Sites } \\
\hline & & $\mathrm{BZAu}$ & BZAd & MRAu & MRAd & $\mathrm{MCAu}$ & MCAd \\
\hline width (m) & $\begin{array}{l}\bar{x} \\
\mathrm{R}\end{array}$ & $\begin{array}{c}0.8^{*} \\
0.4-1.1\end{array}$ & $\begin{array}{c}2.1^{*} \\
0.0-4.0\end{array}$ & $\begin{array}{c}3.1^{*} \\
2.5-5.0\end{array}$ & $\begin{array}{c}4.9^{*} \\
4.0-5.9\end{array}$ & $\begin{array}{c}4.8 \\
4.5-5.5\end{array}$ & $\begin{array}{c}5.2 \\
4.8-6.5\end{array}$ \\
\hline depth (m) & $\begin{array}{l}\overline{\mathrm{X}} \\
\mathrm{R}\end{array}$ & $\begin{array}{c}0.08 \\
0.02-0.11\end{array}$ & $\begin{array}{c}0.1 \\
0.0-0.19\end{array}$ & $\begin{array}{c}0.14 \\
0.08-0.48\end{array}$ & $\begin{array}{c}0.21 \\
0.11-0.4\end{array}$ & $\begin{array}{c}0.39^{*} \\
0.3-5.1\end{array}$ & $\begin{array}{c}0.27^{*} \\
0.14-0.69\end{array}$ \\
\hline current velocity $\left(\mathrm{m} \mathrm{s}^{-1}\right)$ & $\begin{array}{l}\overline{\mathrm{X}} \\
\mathrm{R}\end{array}$ & $\begin{array}{c}0.14 \\
0.06-0.42\end{array}$ & $\begin{array}{c}0.18 \\
0.00-0.305\end{array}$ & $\begin{array}{c}0.06 \\
0.02-0.38\end{array}$ & $\begin{array}{c}0.08 \\
0.06-0.11\end{array}$ & $\begin{array}{c}0.06 \\
0.04-0.08\end{array}$ & $\begin{array}{c}0.06 \\
0.01-0.15\end{array}$ \\
\hline $\mathrm{SI}(\mathrm{mm})$ & $\begin{array}{l}\overline{\mathrm{X}} \\
\mathrm{R}\end{array}$ & $\begin{array}{c}3.4^{*} \\
0.4-6.8\end{array}$ & $\begin{array}{c}0.4^{*} \\
0.3-0.8\end{array}$ & $\begin{array}{c}4.9^{*} \\
0.7-7.7\end{array}$ & $\begin{array}{c}8.9^{*} \\
0.9-16.2\end{array}$ & $\begin{array}{c}0.4^{*} \\
0.3-0.7\end{array}$ & $\begin{array}{c}1.6^{*} \\
0.7-3.5\end{array}$ \\
\hline $\mathrm{BCPOM}\left(\mathrm{g} \mathrm{m}^{-2}\right)$ & $\begin{array}{l}\overline{\mathrm{X}} \\
\mathrm{R}\end{array}$ & $\begin{array}{c}2021 \\
1227-3454\end{array}$ & $\begin{array}{c}2676 \\
1128-4207\end{array}$ & $\begin{array}{c}899 \\
321-1621\end{array}$ & $\begin{array}{c}703 \\
308-1425\end{array}$ & $\begin{array}{c}615^{*} \\
181-809\end{array}$ & $\begin{array}{c}1325^{*} \\
1111-1636\end{array}$ \\
\hline $\mathrm{BFPOM}\left(\mathrm{g} \mathrm{m}^{-2}\right)$ & $\begin{array}{l}\overline{\mathrm{X}} \\
\mathrm{R}\end{array}$ & $\begin{array}{c}5786 \\
3822-8330\end{array}$ & $\begin{array}{c}8952 \\
1785-14663\end{array}$ & $\begin{array}{c}4993^{*} \\
1139-10395\end{array}$ & $\begin{array}{c}295^{*} \\
628-2219\end{array}$ & $\begin{array}{c}6944 \\
1284-15738\end{array}$ & $\begin{array}{c}4088 \\
2310-8841\end{array}$ \\
\hline $\operatorname{TFPOM}\left(\mathrm{g} \mathrm{m}^{-3}\right)$ & $\begin{array}{l}\overline{\mathrm{X}} \\
\mathrm{R}\end{array}$ & $\begin{array}{c}82 \\
1-194\end{array}$ & $\begin{array}{c}76 \\
0-480\end{array}$ & $\begin{array}{c}12 \\
2-32\end{array}$ & $\begin{array}{c}19 \\
1-34\end{array}$ & $\begin{array}{c}15 \\
1-51\end{array}$ & $\begin{array}{c}18 \\
0-57\end{array}$ \\
\hline chlorophyll $a\left(\mathrm{mg} \mathrm{m}^{-2}\right)$ & $\begin{array}{l}\overline{\mathrm{x}} \\
\mathrm{R}\end{array}$ & $\begin{array}{c}119.5^{*} \\
21.8-203.1\end{array}$ & $\begin{array}{c}693.2 * \\
235.9-1143.5\end{array}$ & $\begin{array}{c}183.9 \\
41.5-446.7\end{array}$ & $\begin{array}{c}210.5 \\
55.2-505.1\end{array}$ & $\begin{array}{c}150.4 \\
54.1-597.0\end{array}$ & $\begin{array}{c}186.7 \\
54.5-442.9\end{array}$ \\
\hline temperature $\left({ }^{\circ} \mathrm{C}\right)$ & $\begin{array}{l}\overline{\mathrm{X}} \\
\mathrm{R}\end{array}$ & $\begin{array}{c}9.4 \\
2.1-16.4\end{array}$ & $\begin{array}{c}10.5 \\
2.4-21.3\end{array}$ & $\begin{array}{c}8.9 \\
2.0-15.3\end{array}$ & $\begin{array}{c}11.1 \\
2.4-18.6\end{array}$ & $\begin{array}{c}9.8 \\
3.7-16.8\end{array}$ & $\begin{array}{c}9.9 \\
2.8-17.4\end{array}$ \\
\hline oxygen (mg dm-3) & $\begin{array}{l}\overline{\mathrm{X}} \\
\mathrm{R}\end{array}$ & $\begin{array}{c}4.3 \\
1.0-11.5\end{array}$ & $\begin{array}{c}6.2 \\
3.1-9.5\end{array}$ & $\begin{array}{c}6.8 \\
3.0-10.5\end{array}$ & $\begin{array}{c}7.0 \\
3.7-9.8\end{array}$ & $\begin{array}{c}7.2 \\
3.2-10.1\end{array}$ & $\begin{array}{c}7.1 \\
3.1-10.7\end{array}$ \\
\hline $\mathrm{pH}$ & $\begin{array}{l}\overline{\mathrm{x}} \\
\mathrm{R}\end{array}$ & $\begin{array}{c}6.8 \\
5.5-8.0\end{array}$ & $\begin{array}{c}6.8 \\
5.6-8.4\end{array}$ & $\begin{array}{c}7.2 \\
5.3-8.2\end{array}$ & $\begin{array}{c}7.3 \\
5.5-8.1\end{array}$ & $\begin{array}{c}7.0 \\
5.1-9.0\end{array}$ & $\begin{array}{c}6.9 \\
5.8-9.1\end{array}$ \\
\hline
\end{tabular}

summing the mid point values of size classes weighted by their proportional cover (Quinn \& Hickey 1990).

Data were $\log$ transformed $(\mathrm{x}+1)$, when necessary, to satisfy the requirement of normality and homogeneity of variance (Levene's test). One-way analysis of variance (ANOVA) was used to examine the temporal variance of the environmental variables and of the dominant benthic groups. We also estimated the chironomid diversity (Shannon-Wiener index). Among multivariate techniques we used hierarchical clustering (CLUSTER) and nonmetric multidimensional scaling (NMS) to determine spatial variation between investigated sites based on chironomid assemblages (Clarke \& Warwick 1994; StatSoft 2010).

Further details of the methods are given by Grzybkowska \& Dukowska (2002) and Szczerkowska-Majchrzak et al. (2010).

\section{RESULTS}

\section{Environmental variables}

Statistically significant differences (ANOVA) between the investigated sites, above and below impoundments were recorded for the discharge and width in the Mroga and Bzura Streams, depth of the Mrożyca Stream, granulation of inorganic substrates (SI) of each of the streams, the amount of BFPOM in the Mroga Stream and BCPOM in the Mrożyca Stream and chlorophyll $\alpha$ in the Bzura Stream (Table 1, Figure 2). Note, that the high SI in the upstream site of the Bzura Stream was the effect of a few pebbles scattered on the sand; both these fractions of substrate inorganic particles were covered by high amounts of BFPOM.

\section{Abundance of macroinvertebrates}

Overall the highest mean annual density of macrozoobenthos was recorded in the Bzura Stream above the reservoir (over 25000 ind $\mathrm{m}^{-2}$ ) and it was significantly higher compared with all of the analyzed sites. In contrast the lowest density was

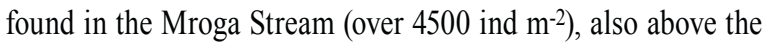
reservoir, and it was significantly lower compared with density downstream of the dam: below the dam of the Mroga Stream and above of the reservoir in the Mrożyca Stream (for those sites ANOVA, Tukey's post hoc $\mathrm{p}<0.002$ ).

Throughout the investigated period benthic invertebrates consisted mainly of dipterans (Chironomidae) and Oligochaeta. 

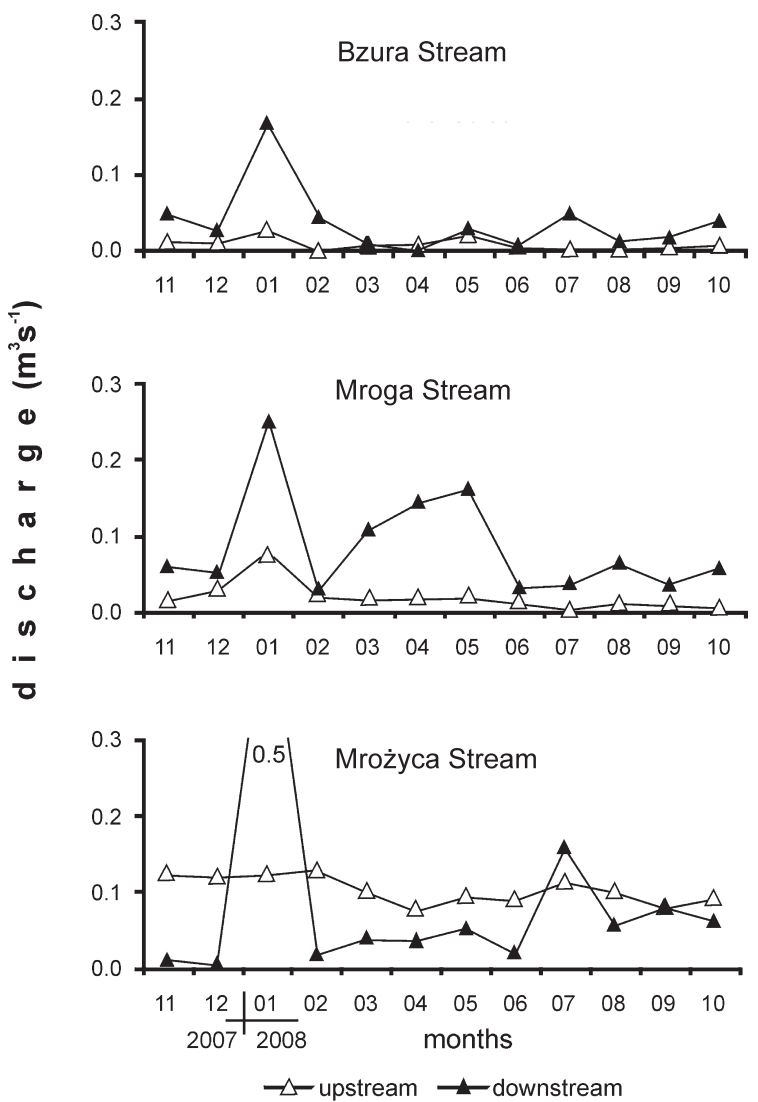

Figure 2. Seasonal dynamics of discharge at the investigated sites of the three small lowland streams.

These midges constituted from about 30 (BZAd, MRAd and MCAd) to over $90 \%$ (MCAu) of the total benthic density. The highest mean annual density of Chironomidae was recorded in the Bzura and Mrożyca Streams above the reservoirs (about 10000 inds $\mathrm{m}^{-2}$ ), while at the other sites they had much lower (BZAd, MCAd, MRAu) and similar values (MRAd) (Figure 3).

\section{Chironomid diversity and abundance}

In the natural reach of the studied streams Chironomidae were dominated either by Chironomini and Prodiamesinae (BZAu, MRAu) or by Chironomini, Tanytarsini and Prodiamesinae (MCAu). In turn at the downstream sites greater number of individuals, such taxa as Orthocladiinae (MRAd) and Tanypodinae (BZAd) were also able to occur (Figure 3). As a consequence chironomid diversity in the altered sites increased; in the Bzura Stream the Shannon-Wiener measure changed from 0.312 to 0.615 (ANOVA, $p=0.0005$ ), in the Mroga Stream from 0.729 to 0.921 ( $\mathrm{p}=0.006$ ), and in the Mrożyca Stream from 0.678 to 0.704 (statistically insignificant).

The highest density was recorded for Chironomus riparius Meigen, 1804; this common species reached over 7500 inds $\mathrm{m}^{-2}$ (mean annual density) at BZAu. However at the other sites this taxon was replaced by other Chironominae: Chironomini such as Stictochironomus sticticus (Fabricius, 1781) (BZAd,
MRAu, MCAu), Polypedilum scalaenum (Schrank, 1803) (BZAd, MCAu, MCAd), Glyptotendipes cauliginellus (Kieffer, 1913) (MRAd), Microtendipes chloris (Meigen, 1818) (MRAd), Paratendipes albimanus (Meigen, 1818) (MRAd) and Polypedilum convictum (Walker, 1856) (MCAu). The last species of those mentioned above was the most abundant Chironomini form followed by $C$. riparius. The most abundant larvae of Chironominae: Tanytarsini were recorded at MCAu - over 3600 inds $\mathrm{m}^{-2}$ for Micropsectra notescens (Walker, 1856), followed by Paratanytarsus sp. (MRAd). At the Mroga Stream Tanytarsini density was 8.5 times lower compared with values of the Mrożyca Stream (Figure 3).

Subfamily Prodiamesinae were represented by Prodiamesa olivacea (Meigen, 1818) with the highest density at BZAu (over 2700 inds $\mathrm{m}^{-2}$ ). For the second species of this subfamily, Odontomesa fulva (Kieffer, 1919) much lower density was recorded (about 150 inds $\mathrm{m}^{-2}$ ); these larvae were dwellers only at MRAu while at the other sites they were absent or accidental. Predatory and/or omnivore Tanypodinae were in significant numbers at BZAu, MRAd (mainly Conchapelopia melanops (Meigen, 1818) and at BZAd (Procladius). Orthocladiinae reached the highest density at MRAd (mainly Cricotopus/ Orthocladius spp.), and, consequently the highest proportion of Orthocladiinae to Chironomini was noted at this site (0.3) while at the other sites these index values did not exceed 0.1 .

Both nonmetric multidimensional scaling ordination NMS and hierarchical clustering (CLUSTER) showed similar results. Because stress index (NMS) for our data was very low $(<0.01)$ we may suppose that this method gives good representation with no prospect of misinterpretation. As you can see axis 1 well separates upstream and downstream for the Mroga Stream whereas the Bzura Streams shows up/down changes best along axis 2 . The relatively short distance of the two investigated sites of the Mrożyca Stream was the effect of H' index being at a similar level (Figure 4, 5).

\section{DISCUSSION}

Dams impact lotic ecosystems in a number of ways by altering the natural flow fluctuations, modifying temperature and oxygen and by fragmenting the continuity of rivers. According to some hydrobiologists, the macrobenthic groups favored by altered conditions below dams include dipterans (Lehmkuhl 1972), especially blackflies (Spence \& Hynes 1971), whereas plecopterans are greatly reduced or absent immediately below reservoirs. In turn Trichoptera and Ephemeroptera may be enhanced or reduced downstream of dams depending on the taxa (Ward \& Stanford 1990; Tszydel et al. 2009). Thus at the downstream sites, the different pattern of macroinvertebrate response, concerning both their quality and quantity, may be observed. In the reach of the Bzura Stream below the impoundment the macroinvertebrate assemblages changed, but Chironomidae and Oligochaeta still dominated, similarly 


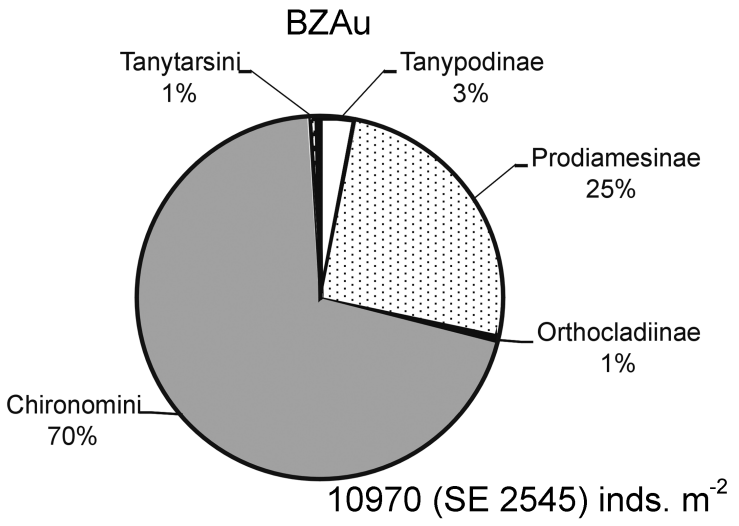

MRAu
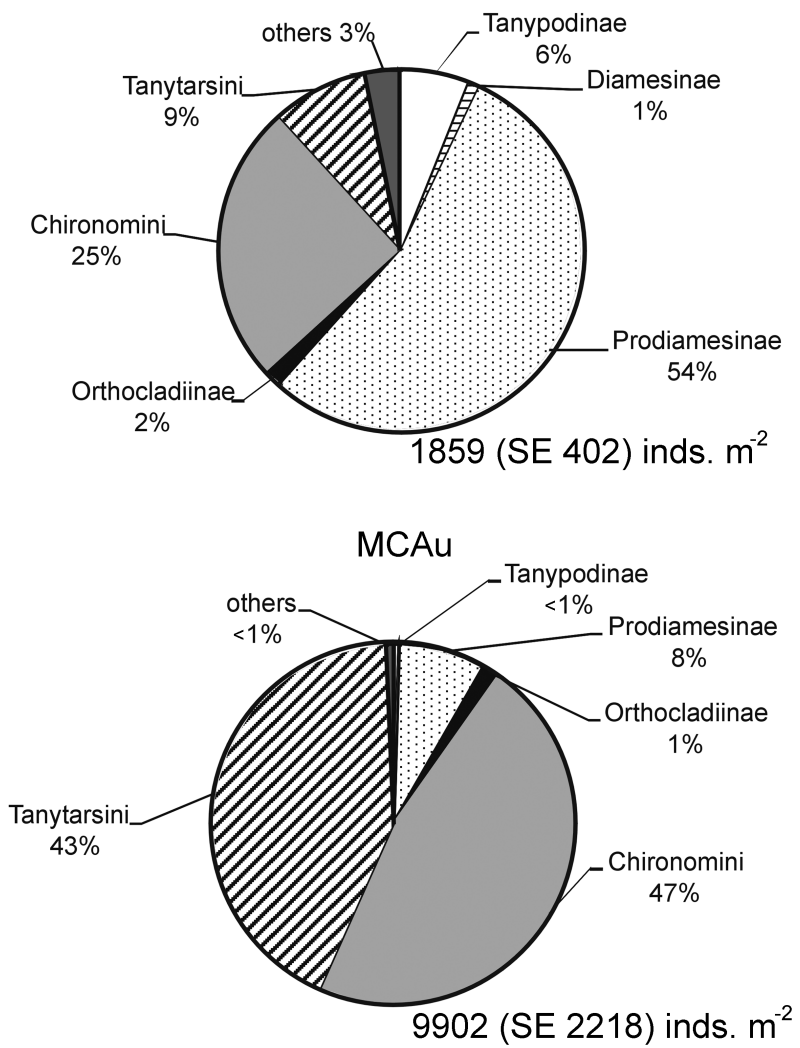

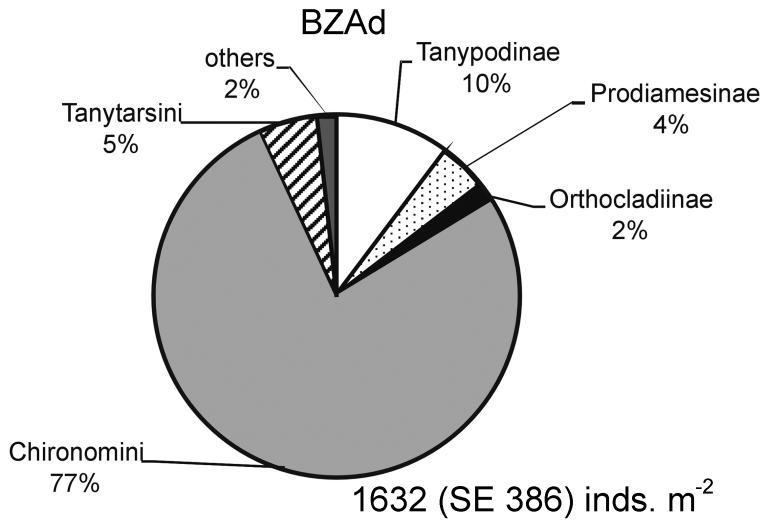

MRAd
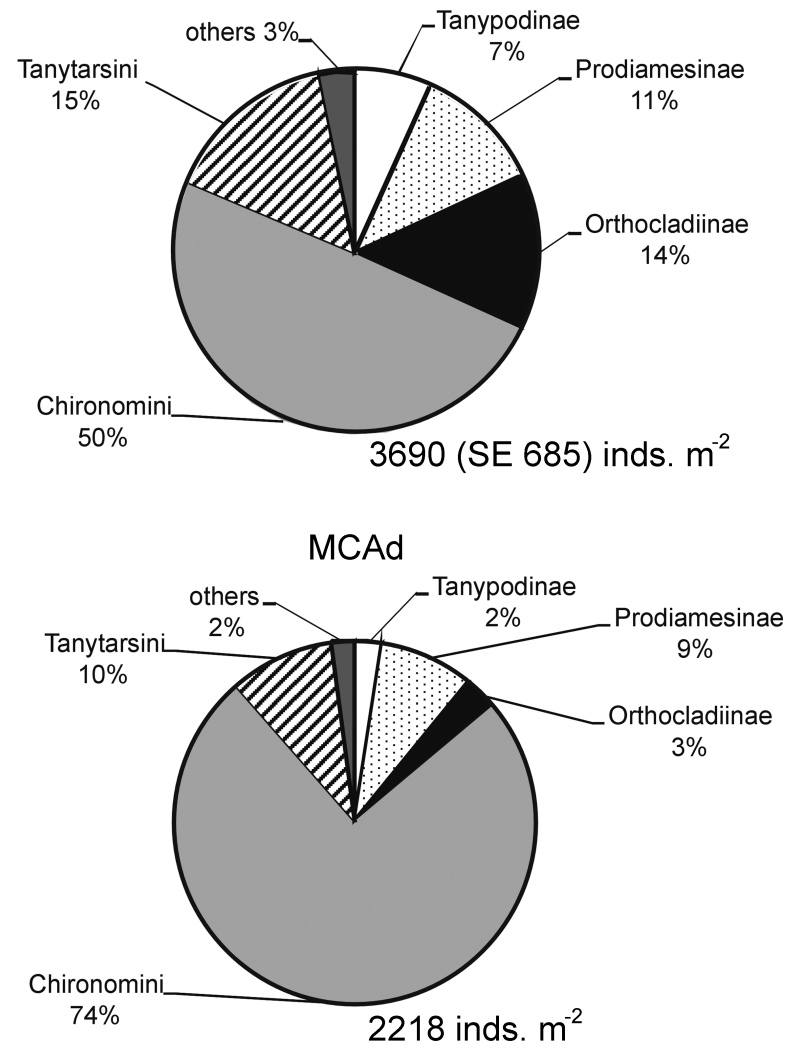

Figure 3. Density percentages of chironomid subfamilies and tribes in the upstream (u) and downstream (d) sites of the three small lowland streams; in the right down corner of each subfigure the mean annual density and standard error (SE) is presented.

to the upstream site, where the most prevalent species was $C$. riparius. Among Chironomidae it is the tribe of Chironomini that occupies the most diverse habitats ranging from oligotrophic to eutrophic rivers and streams (Moller \& Pillot 2009). The genus Chironomus includes red larvae with extraordinary high concentrations of hemoglobins in haemolymph and with haemolymph-filled abdominal tubules that have thin walls associated also with respiration, which are appropriately termed tracheal gills. Thus, the larvae can live in ecosystems with low oxygen level. Frequently this kind of polluted ecosystems, usually as an effect of human activities, disturbs the ecological balance in aquatic environments, and sometimes the eutrophication may lead to population explosion of Chironomus (Ali 1995). In the downstream Bzura Stream, there were high seasonal fluctuations of discharge, from stagnation (due to refilling of the recreation ponds after their emptying and cleaning in spring) to inflow of large volumes of rain water (in winter). This kind of moderate disturbance makes this site more heterogenous than the upstream site, which allows the existence of a much higher number of Chironomini species. Upstream of the dam, a lower species diversity was noted due to almost only $C$. riparius occurring there in high abundance. 


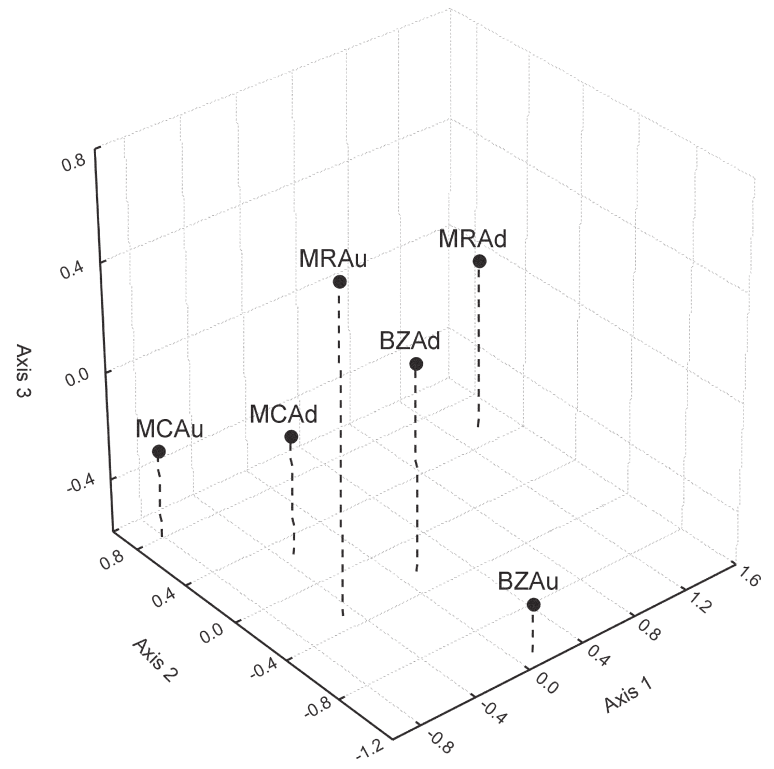

Figure 4. NMS ordination of the 6 sites based on chironomid assemblages.

The main important factors controlling the distribution of riverine macrobenthic assemblages, besides temperature, are flow regime, which also to a large degree regulate availability of food (quality and quantity of food sources, including amount of benthic particulate organic matter, BPOM) are the granulometry of mineral substrate (SI, Minshall \& Robinson 1998). Gravel and pebbles are colonized by a higher number of macroinvertebrates than smaller inorganic particles (sand) because this kind of habitat offers surfaces for attachment on which it is easy to forage and/or construct larval cases, and to develop biofilm (periphyton). It may also constitute important refuges from predators and provide a heterogeneous substrate enabling numerous macroinvertebrates to co-exist (Rabeni \& Minshall 1977; Bournaud et al. 1998; Heino et al. 2004; Dukowska et al. 2007; Szczerkowska-Majchrzak 2010). A similar pattern was observed at the downstream site of the Mroga Stream, where increase in chironomid diversity in comparison with the reference site were noted. This trend was a consequence of higher flow fluctuations, with their potential to sort mineral particles; these events remove and/or redeposit substrate, creating gravel-pebble river bed. Thus below the dam instead of the great number of Prodiamesinae ( $P$. olivacea, O. fulva) and less abundant Chironomini (S. sticticus) a more diverse and abundant chironomid assemblage was able to develop, which was represented not only by Prodiamesinae and Chinonomini, but also by Tanytarsini and Tanypodinae. Thus the diversity of the chironomid assemblage of MRAd form a separate subcluster from the others.

The specific changes in chironomid assemblages between upstream and downstream sites were noted in the Mrożyca Stream. Similarly to the Bzura Stream breaking the of the Mrożyca Stream continuum caused a proportional decrease in

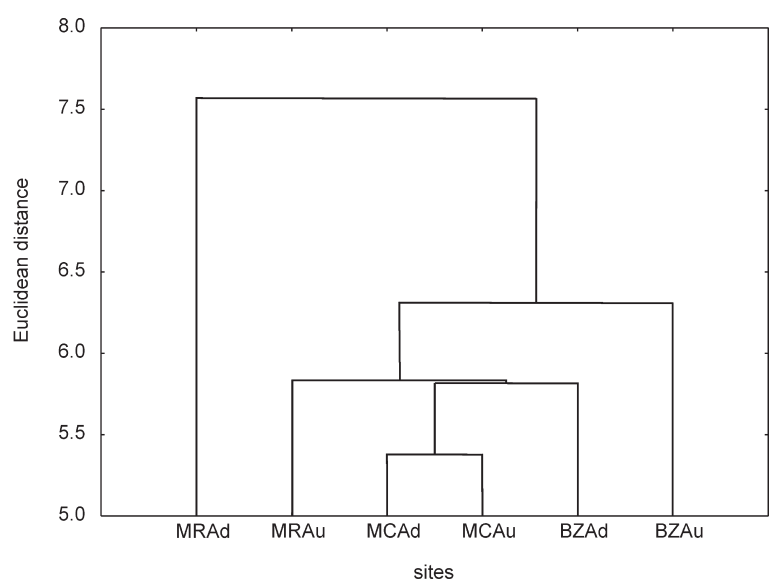

Figure 5. Cluster analysis of the 6 sites based on chironomid assemblages.

the abundance of each dominant taxa, but contrary to the Bzura Stream species diversity of these midges remained at the same level. As a result these two sites of the Mrożyca Stream were close to each other (CLUSTER and NMS).

Our study sites may be compared to urban stream reaches, where the abundance of Ephemeroptera, Trichoptera and Plecoptera (EPT), which are good determinants of discharge changes, were rather low. Our results were due to investigations of Gresens et. al (2007), who stated low densities of EPT in urban reaches as opposed to direct stormwater runoff. However only chironomids at the species and/or genus level were good determinants of discharge changes in altered sandy streams, which in our study was due to breaking the upstreamdownstream continuum.

\section{ACKNOWLEDGMENTS}

This work was partly supported by grant of the Ministry of Science and Higher Education N N304 378138. The authors are also greatly indebted to $\mathrm{dr} \mathrm{M}$. Tszydel and students for assistance with the field work, and dr L. Głowacki for revising the English.

\section{REFERENCES}

Ali A. 1995. Nuisance, economic impact and possibilities for control. In: Armitage PD, Cranston PS and Pinder LCV (eds). The Chironomidae. Biology and ecology of non-biting midges. Chapman \& Hall, London. pp 339-364.

Armitage PD. 1987. The classification of tailwater sites receiving residual flows from upland reservoirs in Great Britain, using macroinvertebrate data. In: Craig JF, Kemper JB. (eds). Regulated Streams. Plenum Publishing Corporation: pp 131-144.

Bednarek AT. 2001. Undamming rivers: a reviews of the ecological impacts of dam removal. Environmental Management 27: 803814. 
Bournaud M, Tachet H, Berly A, Cellot B. 1998. Importance of microhabitat characteristics in the macrobenthos microdistribution of a large river reach. Annales de Limnologie 34: 83-98.

Clarke KR, Warwick RM. 1994. Change in marine communities: an approach to statistical analysis and interpretation. Plymounth: Plymounth Marine Laboratory. pp 144.

Dukowska M, Szczerkowska E, Grzybkowska M, Tszydel M, Penczak T. 2007. Effects of flow manipulations on benthic fauna communities in a lowland river: interhabitat comparison. Polish Journal of Ecology 55: 99-110.

Heino J, Louhi P, Muotka T. 2004. Identifying the scales of variability in stream macroinvertebrate abundance, functional composition and community structure. Freshwater Biology 49: 1230-1239.

Fesl C. 2002. Biodiversity and resourse use of larval chironomids in relation to environmental factors in a large river. Freshwater Biology 47: 1065-1087.

Głowacki Ł, Grzybkowska M, Dukowska M, Penczak T. 2011. Effects of damming a large lowland river on chironomids and fish assessed with (multiplicative partitioning of) true/Hill biodiversity measures. River Research and Applications 27: 612-629.

Golterman HL, Clymo RS, Ohnstad MAM. 1978. Method for chemical analysis of fresh waters. Blackwell Scientific Publication. pp 116-121.

Gresens E, Belt KT, Tang JA, Gwinn DC, Banks PA. 2007. Temporal and spatial responses of Chironomidae (Diptera) and other benthic invertebrates to urban stormwater runoff. Hydrobiologia 575: 173-190.

Grzybkowska M. 1995. Impact of human-induced flow perturbation on the chironomid communities in the first order stream section of the Bzura River (Central Poland). In: Cranston P (ed.). Chironomids - from genes to ecosystems. CSIRO Publications, Melbourne. pp 247-253.

Grzybkowska M, Dukowska M. 2002. Communities of Chironomidae (Diptera) above and below a reservoir on a lowland river: long-term study. Annales Zoologici 52: 235-247.

Grzybkowska M, Głowacki Ł. 2011. Chironomidae (Diptera) diversity in lowland rivers of various orders and of different levels of human impact in central Poland. In: Wang X., Liu W. (eds). Contemporary chironomid studies, Proceedings of the $17^{\text {th }}$ International Symposium on Chironomidae, Nankai University Press, China. pp 282-295.

Lehmann J. 1971. Die Chironomiden der Fulda. Archiv für Hydrobiologie Supplement-Band 37: 466-555.

Lehmkuhl DM. 1972. Change in thermal regime as a cause of reduction of benthic fauna downstream of a reservoir. Journal of the Fisheries Research Board of Canada 29: 1329-1332.

Lenat DR. 1987. The macroinvertebrate fauna of the Little River, North Carolina: taxa list and seasonal trends. Archiv für Hydrobiologie 110: 19-43.

Lindegaard C, Brodersen KP. 1995. Distribution of Chironomidae (Diptera) in the river continuum. In: Cranston P. (ed.). Chironomids: From genes to ecosystems. CSIRO Publications, Melbourne. pp 257-265.

Minshall GW, Robinson CT. 1998. Macroinvertebrate community structure in relation to measures of lotic habitat heterogeneity. Archiv für Hydrobiologie 141: 129-151.
Moller Pillot HKM. 2009. Chironomidae larvae. Biology and ecology of the Chironomini. KNNV Publishing, Zeist, The Netherlands. pp 270.

Palmer AR, O'Keeffe JH 1990. Downstream effects of a small impoundment on a turbid river. Archiv für Hydrobiologie 119: 457-473.

Petersen RC, Cummins KW, Ward GM. 1989. Microbial and animal processing of detritus in a woodland stream. Ecological Monographs 59: 21-39.

Petts GE. 1984. Impounded rivers. Perspectives for ecological management. Wiley and Sons, Chichester. pp 326.

Pinder LCV. 1986. Biology of freshwater Chironomidae. Annual Review of Entomology 31: 1-23.

Quinn JM, Hickey CW. 1990. Magnitude of effects of substrate particle size, recent flooding and catchment development on benthic invertebrates in 88 New Zealand rivers. New Zealand Journal of Marine and Freshwater Research 24: 387409.

Rabeni CF, Minshall GW. 1977. Factors affecting microdistribution of stream benthic insects. Oikos 29: 33-43.

Rossaro B. 1991. Chironomids and water temperature. Aquatic Insects 13: 87-98.

Spence JA, Hynes HGN. 1971. Differences in benthos upstream and downstream of an impoundment. Journal of the Fisheries Research Board of Canada 28: 35-43.

StatSoft. 2010. Statistica for Windows (Computer program manual), ver. 9 .

Szczerkowska-Majchrzak E, Grzybkowska M, Dukowska M. 2010. Effect of flow fluctuations on patch dynamics and chironomid distribution in a medium-sized lowland river. Journal of Freshwater Ecology 25: 437- 448.

Tszydel M, Grzybkowska M, Kruk A. 2009. Influence of dam removal on trichopteran assemblages in the lowland Drzewiczka River, Poland. Hydrobiologia 630: 75-89.

Vinson MR, Hawkins CP. 1998. Biodiversity of stream insects: variation of local, basin, and regional scales. Annual Review of Entomology 43: 271-293.

Ward JS, Stanford JA. 1980. Tailwater biota: ecological response to environmental alternations. In: Proceedings of the symposium on surface water impoundments ASCE, Minneapolis, Minnesota. pp $1516-1525$.

Ward JV, Stanford JA. 1990. Ephemeroptera of the Gunnison River, Colorado, U.S.A. In: Campbell IC (ed). Mayflies and stoneflies. Kluwer Academic Publishers, Dordrecht. pp 215-220. 
Appendix I. Mean annual chironomid density (ind $\mathrm{m}^{-2}$ ) at studied sites; the other explanations as in Table 1.

\begin{tabular}{|c|c|c|c|c|c|c|}
\hline \multirow[b]{2}{*}{ Taxa } & \multicolumn{6}{|c|}{ Sites } \\
\hline & $\mathrm{BZAu}$ & BZAd & MRAu & MRAd & $\mathrm{MCAu}$ & MCAd \\
\hline \multicolumn{7}{|l|}{ Tanypodinae } \\
\hline Apsectrotanypus trifascipennis (Zetterstedt) & 0 & 0 & 0 & 0 & 2 & 0 \\
\hline Conchapelopia melanops (Meigen) & 309 & 12 & 30 & 235 & 2 & 10 \\
\hline Macropelopia nebulosa (Meigen) & 6 & 3 & 44 & 6 & 31 & 14 \\
\hline Procladius Skuse & 28 & 153 & 41 & 5 & 20 & 61 \\
\hline Tanypodinae n. det. & 0 & 0 & 0 & 5 & 0 & 0 \\
\hline \multicolumn{7}{|l|}{ Diamesinae } \\
\hline Potthastia gaedii (Meigen) & 0 & 0 & 16 & 0 & 0 & 0 \\
\hline Diamesinae n. det. & 0 & 0 & 4 & 0 & 0 & 0 \\
\hline \multicolumn{7}{|l|}{ Prodiamesinae } \\
\hline Monodiamesa bathyphila (Kieffer) & 0 & 0 & 19 & 0 & 38 & 55 \\
\hline Odontomesa fulva (Kieffer) & 0 & 3 & 158 & 0 & 23 & 49 \\
\hline Prodiamesa olivacea (Meigen) & 2762 & 67 & 830 & 417 & 714 & 78 \\
\hline Prodiamesinae n. det. & 3 & 0 & 4 & 0 & 0 & 0 \\
\hline \multicolumn{7}{|l|}{ Orthocladiinae } \\
\hline Brillia bifida (Kieffer) & 0 & 0 & 0 & 0 & 6 & 0 \\
\hline Brillia flavifrons (Johansen) & 0 & 0 & 0 & 5 & 5 & 0 \\
\hline Cricotopus sp. & 0 & 0 & 3 & 199 & 0 & 0 \\
\hline Cricotopus sylvestris (Fabricius) & 0 & 0 & 0 & 12 & 0 & 0 \\
\hline Diplocladius cultriger Kieffer & 0 & 0 & 0 & 2 & 0 & 0 \\
\hline Epoicocladius ephemerae (Kieffer) & 0 & 0 & 0 & 0 & 2 & 4 \\
\hline Eukiefferiella brevicalcar (Kieffer) & 0 & 0 & 0 & 50 & 0 & 0 \\
\hline Eukiefferiella claripennis (Lundbeck) & 3 & 0 & 0 & 0 & 0 & 0 \\
\hline Eukiefferiella sp. & 0 & 0 & 0 & 0 & 0 & 2 \\
\hline Heterotrissocladius marcidus (Walker) & 3 & 0 & 0 & 0 & 72 & 16 \\
\hline Heterotrissocladius spp. & 0 & 28 & 11 & 12 & 25 & 0 \\
\hline Nanocladius rectinervis (Kieffer) & 0 & 0 & 4 & 66 & 0 & 8 \\
\hline Orhocladiinae 1 & 58 & 0 & 0 & 0 & 0 & 0 \\
\hline Orhocladiinae 2 & 3 & 0 & 0 & 0 & 0 & 0 \\
\hline Parametriocnemus sp. & 0 & 0 & 0 & 0 & 21 & 0 \\
\hline Paraphaenocladius sp. & 0 & 0 & 4 & 0 & 0 & 0 \\
\hline Paratrichocladius sp. & 0 & 0 & 0 & 5 & 0 & 0 \\
\hline Psectrocladius sp. & 0 & 0 & 4 & 0 & 0 & 0 \\
\hline Rheocricotopus sp. & 3 & 0 & 0 & 116 & 3 & 18 \\
\hline Synorthocladius semivirens (Kieffer) & 0 & 0 & 0 & 0 & 2 & 0 \\
\hline Thienemanniella clavicornis (Kieffer) & 0 & 0 & 0 & 0 & 0 & 2 \\
\hline Orhocladiinae n. det. & 3 & 0 & 4 & 41 & 11 & 16 \\
\hline \multicolumn{7}{|l|}{ Chironomini } \\
\hline Chironomus riparius Meigen & 7645 & 28 & 11 & 79 & 2 & 20 \\
\hline Cryptochironomus borysthenicus Chernovskij & 0 & 0 & 0 & 0 & 17 & 0 \\
\hline Cryptochironomus defectus (Kieffer) & 3 & 98 & 0 & 14 & 29 & 133 \\
\hline Dicrotendipes nervosus (Staeger) & 6 & 86 & 0 & 47 & 0 & 4 \\
\hline
\end{tabular}


Appendix I. Continued.

\begin{tabular}{|c|c|c|c|c|c|c|}
\hline \multirow[b]{2}{*}{ Taxa } & \multicolumn{6}{|c|}{ Sites } \\
\hline & $\mathrm{BZAu}$ & BZAd & MRAu & MRAd & $\mathrm{MCAu}$ & MCAd \\
\hline Endochironomus albipennis (Meigen) & 0 & 0 & 0 & 46 & 0 & 0 \\
\hline Endochironomus sp. 1 & 0 & 9 & 3 & 46 & 0 & 8 \\
\hline Endochironomus sp. 2 & 0 & 0 & 15 & 20 & 0 & 4 \\
\hline Endochironomus tendens (Fabricius) & 0 & 0 & 0 & 2 & 0 & 0 \\
\hline Glyptotendipes cauliginellus (Kieffer) & 3 & 0 & 0 & 414 & 0 & 0 \\
\hline Glyptotendipes paripes (Edwards) & 0 & 0 & 3 & 5 & 0 & 0 \\
\hline Microtendipes chloris (Meigen) & 0 & 79 & 48 & 729 & 232 & 287 \\
\hline Parachironomus gracilior (Kieffer) & 0 & 0 & 0 & 11 & 2 & 2 \\
\hline Paracladopelma camptolabis (Kieffer) & 0 & 3 & 7 & 8 & 26 & 20 \\
\hline Paratendipes albimanus (Meigen) & 6 & 76 & 62 & 237 & 179 & 61 \\
\hline Polypedilum convictum (Walker) & 0 & 0 & 0 & 5 & 2064 & 66 \\
\hline Polypedilum nubeculosum (Meigen) & 6 & 31 & 0 & 29 & 0 & 24 \\
\hline Polypedilum pedestre (Meigen) & 0 & 3 & 0 & 3 & 2 & 0 \\
\hline Polypedilum scalaenum (Schrank) & 3 & 180 & 38 & 41 & 1589 & 986 \\
\hline Polypedilum sp. & 0 & 0 & 0 & 12 & 29 & 8 \\
\hline Stictochironomus sticticus (Fabricius) & 3 & 645 & 275 & 37 & 434 & 4 \\
\hline Chironomini n. det & 6 & 15 & 7 & 47 & 21 & 22 \\
\hline \multicolumn{7}{|l|}{ Tanytarsini } \\
\hline Cladotanytarsus mancus (Walker) & 0 & 0 & 12 & 2 & 162 & 53 \\
\hline Micropsectra notescens (Walker) & 31 & 12 & 79 & 110 & 3697 & 152 \\
\hline Paratanytarsus sp. 1 & 0 & 0 & 15 & 98 & 0 & 0 \\
\hline Paratanytarsus sp. 2 & 0 & 46 & 0 & 238 & 0 & 0 \\
\hline Rheotanytarsus sp. & 0 & 0 & 0 & 78 & 0 & 0 \\
\hline Tanytarsus sp. & 0 & 0 & 42 & 17 & 0 & 0 \\
\hline Tanytarsini n. det. & 43 & 28 & 10 & 23 & 377 & 9 \\
\hline Chironomidae n. det. & 34 & 28 & 60 & 119 & 69 & 43 \\
\hline Total & 10970 & 1632 & 1859 & 3690 & 9902 & 2243 \\
\hline
\end{tabular}

